\title{
Pengaruh pH Awal dan Suhu Penyimpanan terhadap Stabilitas Betasianin Ekstrak Pewarna dari Bunga Kenop (Gomphrena globosa L.)
}

The effect of Initial pH and Storage Temperature on the Stability of Betacyanin Dye Extract from Globe amaranth (Gomphrena globosa L.)

\section{Made Sugiastawa, Ni Made Wartini*, I Wayan Arnata}

PS Teknologi Industri Pertanian, Fakultas Teknologi Pertanian, Universitas Udayana, Kampus Bukit

Jimbaran, Badung, Kode pos : 80361; Telp/Fax : (0361) 701801

Diterima 21 September 2021 / Disetujui 06 Oktober 2021

\begin{abstract}
Globe amaranth is a flower that can be used as a natural dye. The flower has a high betacyanin. This study aimed to determine the effect of initial $\mathrm{pH}$ and the temperature in stability extent of globe amaranth dye extract, with determined the initial $\mathrm{pH}$ and globe amaranth flower temperature with the maximum stability of dye extract during the retention. This experiment used a complete randomized design with two factors. The first factor was the initial $\mathrm{pH}$ that consist of $\mathrm{pH} 4, \mathrm{pH} 5$, and $\mathrm{pH}$ 6. The second factor was the storage temperature consist of temperature $4 \pm 1^{\circ} \mathrm{C}$ and temperature $28 \pm 2^{\circ} \mathrm{C}$. The data were analyzed through analysis of variance in determined the effect of each factors. The results showed the initial $p H$ had significant effect on betacyanin levels and value of brightness level $\left(L^{*}\right)$, redness level $\left(a^{*}\right)$, and yellowish level $\left(b^{*}\right)$ during the storage of globe amaranth dye extract. The temperature had significant effect on betacyanin levels and the value of brightness level $\left(L^{*}\right)$, value of the level of redness $\left(a^{*}\right)$ on the third and fourth weeks, and a significant effect of yellowish $\left(b^{*}\right)$ only on the first and third weeks, a significant effect of yellowness $\left(b^{*}\right)$ on the fourth week. The interaction of two treatments had significant effect in every week on betacyanin levels and the value of the brightness level $\left(L^{*}\right)$ on the first and second weeks, the value of the level of redness ( $\left.a^{*}\right)$ on the second week, and significant effect of the yellowish level $\left(b^{*}\right)$ on third and fourth weeks. The dye extract from the globe amaranth was stable at initial $\mathrm{pH} 4$ with $\left(4 \pm l^{\circ} \mathrm{C}\right)$ cold temperature during the storage. During the control retention of globe amaranth dye extract within four weeks caused a decrease on betacyanin levels $34.76 \%$, redness level value $\left(a^{*}\right) 61.85 \%$, and it was an increase of brightness level $\left(L^{*}\right) 70,91 \%$, the value of yellowish level ( $b *) 67.21 \%$.
\end{abstract}

Keywords : Globe amaranth extract, betacyanin, $p H$, temperature, stability.

\begin{abstract}
ABSTRAK
Bunga kenop merupakan bunga yang dapat dimanfaatkan sebagai sumber pewarna alami. Bunga ini memiliki kandungan betasianin yang cukup tinggi. Penelitian ini bertujuan untuk mengetahui pengaruh $\mathrm{pH}$ awal dan suhu terhadap stabilitas ekstrak pewarna serta menentukan $\mathrm{pH}$ awal dan suhu penyimpanan yang memberikan stabilitas terbaik terhadap ekstrak pewarna bunga kenop selama penyimpanan. Percobaan ini dirancang menggunakan Rancangan Acak Lengkap dengan dua faktor. Faktor pertama adalah $\mathrm{pH}$ awal yang terdiri atas
\end{abstract}

*Korespondensi Penulis:

Email: md_wartini@unud.ac.id 
$\mathrm{pH} 4$, pH 5, dan $\mathrm{pH}$ 6. Faktor kedua adalah suhu penyimpanan yang terdiri atas suhu $4 \pm 1^{\circ} \mathrm{C}$ dan suhu $28 \pm 2^{\circ} \mathrm{C}$. Data dianalisis dengan Analysis of variance untuk mengetahui pengaruh dari setiap faktor. Hasil penelitian menunjukkan bahwa $\mathrm{pH}$ awal berpengaruh sangat nyata terhadap kadar betasianin, nilai tingkat kecerahan $\left(\mathrm{L}^{*}\right)$, tingkat kemerahan $\left(\mathrm{a}^{*}\right)$, dan tingkat kekuningan $\left(\mathrm{b}^{*}\right)$ selama penyimpanan ekstrak pewarna bunga kenop. Suhu berpengaruh sangat nyata terhadap kadar betasianin dan nilai tingkat kecerahan $\left(\mathrm{L}^{*}\right)$, dan berpengaruh sangat nyata terhadap nilai tingkat kemerahan $\left(a^{*}\right)$ pada minggu ke-3 dan 4 , serta berpengaruh sangat nyata terhadap nilai tingkat kekuningan $\left(\mathrm{b}^{*}\right)$ pada minggu ke-1 dan 3 , hanya berpengaruh nyata terhadap nilai tingkat kekuningan $\left(b^{*}\right)$ pada minggu ke-4. Interaksi kedua perlakuan berpengaruh sangat nyata setiap minggunya terhadap kadar betasianin, dan berpengaruh sangat nyata terhadap nilai tingkat kecerahan $\left(\mathrm{L}^{*}\right)$ pada minggu ke-1 dan 2, hanya berpengaruh nyata terhadap nilai tingkat kemerahan (a*) pada minggu ke-2, dan berpengaruh sangat nyata terhadap nilai tingkat kekuningan ( $\left.b^{*}\right)$ pada minggu ke-3 dan 4 . Ekstrak pewarna dari bunga kenop paling stabil pada $\mathrm{pH}$ awal 4 dan suhu dingin $\left(4 \pm 1^{\circ} \mathrm{C}\right)$ selama penyimpanan. Penyimpanan ekstrak pewarna bunga kenop selama 4 minggu menyebabkan penurunan kadar betasianin sebesar $34,76 \%$, nilai tingkat kemerahan (a*) sebesar $61,85 \%$, namun menyebabkan peningkatan nilai tingkat kecerahan $\left(\mathrm{L}^{*}\right)$ sebesar $70,91 \%$, nilai tingkat kekuning-kuningan $\left(b^{*}\right)$ sebesar $67,21 \%$ terhadap kontrol.

Kata kunci : Ekstrak bunga kenop, betasianin, pH, suhu, stabilitas

\section{PENDAHULUAN}

Tanaman bunga kenop (Gomphrena globosa L.) merupakan tanaman liar yang dapat tumbuh sampai ketinggian $1.400 \mathrm{~m}$ di atas permukaan laut dan juga pada tempattempat yang cukup mendapat sinar matahari (Wijayakusuma, 2000). Berdasarkan keterangan dari petani bunga kenop yang berasal dari Banjar Celagi, Kabupaten Tabanan, tanaman bunga kenop dapat menghasilkan rata-rata $16 \mathrm{~kg}$ bunga dari luas lahan $100 \mathrm{~m}^{2}$ dalam sekali pemanenan. Bunga kenop mengandung komponen kimia alami yang berasal dari kelompok betasianin sebesar $1,3 \mathrm{mg} / \mathrm{g}$ sampel segar yang dapat dimanfaatkan sebagai sumber pewarna alami (Cai et al., 2001).

Betasianin merupakan salah satu zat warna yang dapat dimanfaatkan sebagai zat warna alami untuk pangan dan sebagai alternatif pengganti zat warna sintetik karena memiliki warna yang menarik, mudah larut dalam air, dan mempunyai aktifitas antioksidan yang tinggi (Herbach et al., 2006). Ekstrak pewarna dari bunga kenop bisa didapatkan melalui proses ekstraksi, salah satunya dengan metode maserasi menggunakan pelarut etanol $48 \%$ dan suhu $25^{\circ} \mathrm{C}$ didapatkan ekstrak pewarna dengan total betasinain $185,51 \mathrm{mg} / 100 \mathrm{~g}$ (Fikri et al., 2020). Maserasi merupakan proses perendaman sampel menggunakan pelarut organik pada suhu ruangan (Darwis, 2000). Metode ini relative lebih mudah dan murah dibandingkan dengan metode ekstraksi lainnya, seperti perkolasi, digesti, infusa, refluks, soxhletasi, microwave assisted extraction dan ultrasound assisted extraction . Selain itu maserasi merupakan jenis ekstrasi dingin yang cocok untuk mengekstrak pigmen betasianin yang termasuk senyawa antioksidan yang sangat sensitif terhadap suhu panas.. Proses ekstraksi bunga kenop menghasilkan ekstrak pewarna cair yang dapat langsung diaplikasikan pada makanan, ataupun disimpan sebagai bahan pewarna. Proses penyimpanan dapat mempengaruhi kestabilan warna dari ekstrak. Kerusakan ekstrak pewarna betasianin pada saat penyimpanan biasanya disebabkan oleh beberapa faktor antara lain $\mathrm{pH}$, suhu, cahaya matahari, sinar lampu dan oksidator (Rengku et al., 2017). Dalam penelitian ini dipilih dua faktor yaitu $\mathrm{pH}$ awal dan suhu penyimpanan, kedua faktor ini dipilih karena betasianin sangat sensitif terhadap perubahan $\mathrm{pH}$ awal dan suhu selama penyimpanan.

Beberapa penelitian mengenai stabilitas betasianin telah dilakukan, 
diantaranya penelitian dari Asra et al. (2020) melaporkan bahwa pigmen betasianin menjadi semakin tidak stabil ditandai dengan perubahan warna ekstrak dari berwarna merah menjadi kekuningan dipengaruhi oleh $\mathrm{pH}$. Penelitian yang dilakukan oleh Rengku et al. (2017) melaporkan betasianin yang terdapat di dalam ekstrak buah kaktus (Opuntia elatior Mill.) cenderung stabil pada perlakuan $\mathrm{pH}$ awal 4 hingga 6 selama 3 hari penyimpanan. Selain itu Otalora et al. (2020) yang melaporkan ekstrak betalain yang terkandung dalam umbi bit (Beta vulgaris) lebih stabil pada suhu $5^{\circ} \mathrm{C}$ dan $25^{\circ} \mathrm{C}$ dibandingkan dengan pada suhu $45^{\circ} \mathrm{C}$ selama 6 hari penyimpanan.

Kondisi penyimpanan ekstrak pewarna sangat menentukan stabilitas warna dan kandungan betasianin dalam suatu bahan. Sehingga penelitian pengaruh $\mathrm{pH}$ awal dan suhu penyimpanan terhadap stabilitas ekstrak pewarna dari bunga kenop perlu dilakukan untuk mengetahui kondisi optimum yang dapat mempertahankan stabilitas ekstrak pewarna dari bunga kenop. Tujuan dari penelitian ini adalah mengetahui pengaruh $\mathrm{pH}$ awal dan suhu penyimpanan terhadap stabilitas ekstrak pewarna bunga kenop, serta menentukan $\mathrm{pH}$ awal dan suhu yang memberikan stabilitas terbaik terhadap ekstrak pewarna bunga kenop selama penyimpanan.

\section{METODE PENELITIAN}

\section{Bahan dan Alat}

Bahan yang digunakan dalam
penelitian ini adalah bunga kenop
(Gomphrena globosa L.) dengan kriteria
bunga berwarna ungu dengan ukuran bunga
$20-25$ mm dengan bentuk bulat yang
diperoleh dari Jalan Celagi, Banjar Celagi,
Desa Denbantas, Kecamatan Tabanan,
Kabupaten Tabanan, Provinsi Bali. Bahan
kimia yang digunakan etanol teknis 48\%, air
distilasi, asam galat (Sigma-aldrich) dan

kristal DPPH (Himedia), larutan buffer sitrat pH 4 (Merck), buffer sitrat pH 5 (Merck), dan buffer sitrat $\mathrm{pH} 6$ (Merck), buffer sitrat phospat pH 5 (Merck), metanol (Merck) yang semuanya memiliki grade pro analysis.

\section{Pelaksanaan Penelitian}

Preparasi sampel diawali dengan bunga kenop dihilangkan kelopaknya dan dicuci menggunakan air hingga bersih. Selanjutnya dilakukan blansir pada suhu $95 \pm 2^{\circ} \mathrm{C}$ selama 3 detik dan didinginkan dengan air dingin (Estiatih et al., 2014). Bunga kenop kemudian dioven pada suhu $40 \pm 5^{\circ} \mathrm{C}$ hingga mudah dihancurkan (kadar air $\pm 8,44 \%$ ). Selanjutnya dihaluskan menggunakan blender dan diayak menggunakan ayakan ukuran 80 mesh.

Bubuk bunga kenop diekstrak dengan metode maserasi dan menggunakan pelarut etanol $48 \%$. Bunga kenop yang sudah diayak ditimbang seberat $20 \mathrm{~g}$ kemudian ditambahkan pelarut etanol $48 \%$ sebanyak $220 \mathrm{~mL}(1: 11)(\mathrm{b} / \mathrm{v})$ (Yudharini et al., 2016). Kemudian dilakukan maserasi selama 36 jam pada suhu ruang. Pengadukan dilakukan manual setiap 6 jam selama 5 menit. Selanjutnya ekstrak disaring menggunakan kertas saring kasar yang menghasilkan filtrat I dan ampas. Kemudian ampas ditambah pelarut sebanyak $20 \mathrm{~mL}$ digojog selama 5 menit, lalu disaring dengan kertas saring kasar dan menghasilkan filtrat II. Filtrat I dan II dicampur dan disaring dengan ketas saring Whatman No. 1. Sehingga diperoleh ekstrak yang masih tercampur dengan pelarut. Ekstrak kemudian dimasukkan ke dalam labu rotary vacuum evaporator dievaporasi pada suhu $50^{\circ} \mathrm{C}$ dengan tekanan $100 \mathrm{mBar}$ untuk menghilangkan dan pelarut yang terdapat dalam ekstrak sehingga didapatkan ekstrak kental. Evaporasi dihentikan pada saat semua pelarut sudah menguap yang ditandai dengan tidak adanya tetesan pelarut. Ekstrak kental yang diperoleh dimasukkan ke dalam botol sampel.

Proses penyimpanan dilakukan dengan 
sebagai berikut: ekstrak bunga kenop sebanyak $\pm 1 \mathrm{~g}$ ditimbang untuk masingmasing perlakuan, kemudian dimasukkan dalam botol kaca gelap (Rengku et al., 2017). Sampel ekstrak bunga kenop kemudian diatur pH awalnya dengan cara ditambahkan larutan buffer sesuai perlakuan yaitu $\mathrm{pH} 4,5$, dan 6 hingga seluruh bagian ekstrak terendam larutan buffer $( \pm 10 \mathrm{~mL})$. Kemudian ekstrak disimpan pada suhu sesuai perlakuan yaitu suhu $4 \pm 1^{\circ} \mathrm{C}$ yang disimpan dalam kulkas dan suhu $28 \pm 2^{\circ} \mathrm{C}$ disimpan di dalam ruangan. Dilakukan uji stabilitas betasianin ekstrak pewarna bunga kenop selama 4 minggu (Tang dan Norziah, 2007). Pengamatan dilakukan setiap minggu dengan cara mengambil bagian ekstrak yang terendam dengan larutan buffer sebanyak 0,05 g.

\section{Variabel yang Diamati}

Variabel yang diamati dalam penelitian adalah kadar betasianin (Eder, 1996) dan intensitas warna sistem $\mathrm{L}^{*}, \mathrm{a}^{*}, \mathrm{~b}^{*}$ (Weaver, 1996). Analisis dilakukan terhadap ekstrak yang belum disimpan dan ekstrak yang telah mengalami penyimpanan.

\section{HASIL DAN PEMBAHASAN}

\section{Kadar Betasianin Selama Penyimpanan}

Kadar betasianin kontrol ekstrak pewarna dari bunga kenop adalah sebesar $374,90 \mathrm{mg} / 100 \mathrm{~g}$. Pengamatan uji stabilitas ekstrak pewarna dari bunga kenop menunjukkan bahwa semua perlakuan $\mathrm{pH}$ awal dan suhu pada penyimpanan ekstrak pewarna dari bunga kenop mengakibatkan penurunan kadar betasianin selama 4 minggu penyimpanan.

Hasil analisis ragam menunjukkan bahwa perlakuan $\mathrm{pH}$ awal, suhu dan interaksi keduanya berpengaruh sangat nyata $(\mathrm{p}<0,01)$ terhadap kadar betasianin pada minggu ke-1, ke-2, ke-3 dan ke-4. Hal ini sesuai dengan penelitian yang dilakukan oleh Paranoan et al. (2017) yang menyatakan bahwa perlakuan variasi $\mathrm{pH}$ memberikan pengaruh yang sangat nyata terhadap kadar total betasianin ekstrak hasil kulit buah naga merah. Nilai rata-rata kadar betasianin selama penyimpanan disajikan dalam Tabel 1.

Tabel 1. Nilai rata-rata kadar betasianin $(\mathrm{mg} / 100 \mathrm{~g})$ ekstrak bunga kenop pada perlakuan $\mathrm{pH}$ awal dan suhu penyimpanan pada mingu ke-1 sampai minggu ke-4

\begin{tabular}{|c|c|c|c|c|}
\hline \multirow[b]{2}{*}{ Perlakuan } & \multicolumn{4}{|c|}{ Rata-rata kadar betasianin $\pm \mathrm{SD}(\mathrm{mg} / \mathbf{1 0 0 g})$} \\
\hline & Minggu 1 & Minggu 2 & Minggu 3 & Minggu 4 \\
\hline pH 4; $\left(4 \pm 1^{\circ} \mathrm{C}\right)$ & $286,57 \pm 3,00 \mathrm{a}$ & $258,80 \pm 2,75 \mathrm{a}$ & $255,62 \pm 1,76 \mathrm{a}$ & $244,58 \pm 1,53 \mathrm{a}$ \\
\hline pH $5 ;\left(4 \pm 1^{\circ} \mathrm{C}\right)$ & $283,39 \pm 3,99 a$ & $257,29 \pm 2,26 \mathrm{a}$ & $242,57 \pm 2,02 b$ & $235,71 \pm 2,02 b$ \\
\hline pH 6; $\left(4 \pm 1^{\circ} \mathrm{C}\right)$ & $8,03 \pm 1,11 \mathrm{~d}$ & $5,35 \pm 0,29 \mathrm{~d}$ & $5,02 \pm 0,50 \mathrm{e}$ & $5,02 \pm 0,29 \mathrm{e}$ \\
\hline pH 4; $\left(28 \pm 2^{\circ} \mathrm{C}\right)$ & $236,55 \pm 3,01 b$ & $181,51 \pm 2,75 b$ & $120,62 \pm 2,75 \mathrm{c}$ & $81,3 \pm 2,50 \mathrm{c}$ \\
\hline pH 5; $\left(28 \pm 2^{\circ} \mathrm{C}\right)$ & $212,46 \pm 3,01 \mathrm{c}$ & $160,43 \pm 3,75 \mathrm{c}$ & $59,56 \pm 3,25 \mathrm{~d}$ & $45,34 \pm 1,76 \mathrm{~d}$ \\
\hline pH 6; $\left(28 \pm 2^{\circ} \mathrm{C}\right)$ & $5,52 \pm 1,01 \mathrm{~d}$ & $5,02 \pm 0,50 \mathrm{~d}$ & $4,52 \pm 0,50 \mathrm{e}$ & $4,18 \pm 0,29 \mathrm{e}$ \\
\hline
\end{tabular}

Tabel 1 menunjukkan bahwa pada minggu ke-1 dan 2 kadar betasianin pada perlakuan $\mathrm{pH}$ awal 4 dengan penyimpanan suhu $4 \pm 1^{\circ} \mathrm{C}$ tidak berbeda nyata dengan 
perlakuan $\mathrm{pH}$ awal 5 pada suhu $4 \pm 1^{\circ} \mathrm{C}$, perlakuan $\mathrm{pH}$ awal 6 pada suhu $4 \pm 1^{\circ} \mathrm{C}$ menghasilkan kadar betasianin yang tidak berbeda nyata dengan perlakuan $\mathrm{pH} 6$ pada suhu $28 \pm 2^{\circ} \mathrm{C}$, namun berbeda nyata dengan perlakuan lainnya. Pada minggu ke-3 dan 4 perlakuan $\mathrm{pH}$ awal 6 dengan penyimpanan suhu $4 \pm 1^{\circ} \mathrm{C}$ menunjukkan kadar betasianin yang tidak berbeda nyata dengan perlakuan $\mathrm{pH}$ awal 6 dengan penyimpanan suhu $28 \pm 2^{\circ} \mathrm{C}$, tetapi berbeda nyata dengan perlakuan lainnya. Perlakuan $\mathrm{pH}$ awal 4 dan suhu $4 \pm 1^{\circ} \mathrm{C}$ menghasilkan rata-rata kadar betasianin tertinggi pada setiap minggu penyimpanan. Hal ini menunjukkan bahwa betasianin pada ekstrak pewarna bunga kenop paling stabil pada perlakuan tersebut, ini dikarenakan pigmen betasianin pada perlakuan $\mathrm{pH}$ awal 4 dengan penyimpanan suhu $4 \pm 1^{\circ} \mathrm{C}$ paling sedikit mengalami degradasi menjadi pigmen betaxiantin selama penyimpanan dibandingkan dengan perlakuan lainnya. Menurut Herbach et al. (2006) peningkatan $\mathrm{pH}$, intensitas cahaya, oksigen dan ion logam dapat mempengaruhi kestabilan betasianin. Betasianin pada kulit buah naga merah lebih stabil pada suhu dingin $<14^{\circ} \mathrm{C}$ dibandingkan dengan suhu ruang, hal ini dikarenakan struktur pigmen rusak yang menyebabkan konsentrasi pigmen menurun (Faridah, 2016). Grafik penurunan kadar betasianin dari kontrol hingga minggu ke-4 disajikan dalam Gambar 1.

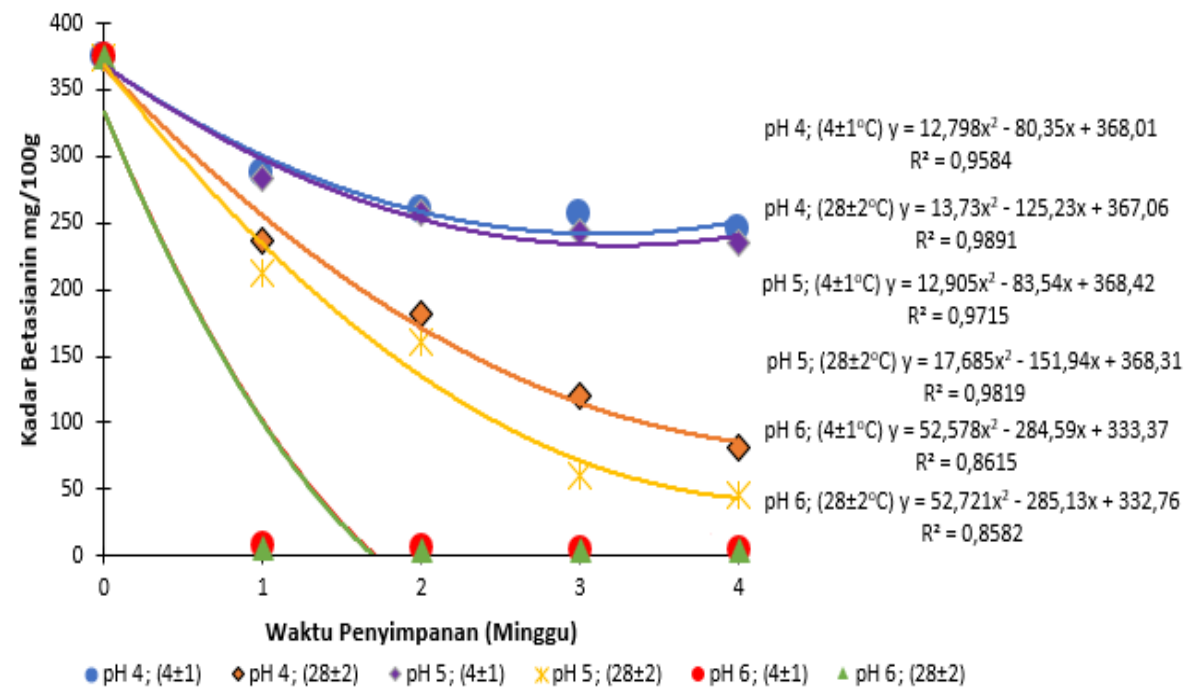

Gambar 1. Grafik penurunan kadar betasianin ekstrak pewarna dari bunga kenop selama penyimpanan pada perlakuan $\mathrm{pH}$ awal dan suhu

Gambar 1 menunjukkan model hubungan antara waktu penyimpanan dengan kadar betasianin mempunyai nilai nilai determinasi $\left(\mathrm{R}^{2}\right)$ berkisar antara 0,8582 sampai dengan 0,9891. Hal ini menunjukkan bahwa waktu penyimpanan berpengaruh terhadap kadar betasianin pada ekstrak pewarna bunga kenop. Nilai determinasi tertinggi sebesar 0,9891 diperoleh dari perlakuan $\mathrm{pH}$ awal 4 dengan penyimpanan suhu $28 \pm 2^{\circ} \mathrm{C}$. Ini menunjukkan bahwa
98,91\% kadar betasianin ekstrak pewarna dari bunga kenop dipengaruhi oleh waktu penyimpanan. Sebanyak 1,09\% kadar betasianin di pengaruhi oleh cahaya matahari, sinar lampu dan oksidator, (Rengku et al., 2017)

Gambar 1 menunjukkan persamaan regresi untuk masing-masing perlakuan dengan persamaan umum adalah $\mathrm{y}=\mathrm{ax}^{2}+\mathrm{bx}$ + c (Satriyanto et al., 2012). Semua persamaan memiliki nilai koefisien $b$ bernilai 
negatif (-). Ini menunjukkan korelasi antara kadar betasianin dengan waktu penyimpanan berbanding terbalik, artinya semakin lama waktu penyimpanan maka semakin rendah kadar betasianin yang terdapat dalam ekstrak pewarna dari bunga kenop dan sebaliknya. Persamaan regresi pada perlakuan $\mathrm{pH}$ awal 4 dan penyimpanan pada suhu $4 \pm 1^{\circ} \mathrm{C}$ memiliki koefisien persamaan lebih kecil dibandingkan dengan persamaan pada perlakuan lainnya. Ini menunjukkan penurunan kadar betasianin terkecil diperoleh pada perlakuan $\mathrm{pH}$ awal 4 dan penyimpanan pada suhu $4 \pm 1^{\circ} \mathrm{C}$. Pada perlakuan $\mathrm{pH}$ awal 6 dan suhu $28 \pm 2^{\circ} \mathrm{C}$ memiliki koefisien persamaan lebih besar dibandingkan dengan persamaan pada perlakuan lainnya. Hal ini berarti kadar betasianin pada ekstrak bunga kenop paling tidak stabil pada perlakuan $\mathrm{pH}$ awal 6 dan suhu $28 \pm 2^{\circ} \mathrm{C}$ dibandingkan dengan perlakuan lainnya. Ini dikarenakan pada perlakuan $\mathrm{pH}$ awal 4 dengan suhu penyimpanan $4 \pm 1^{\circ} \mathrm{C}$ pigmen betasianin pada ekstrak pewarna dari bunga kenop tidak mengalami perubahan menjadi pigmen betaxiantin selama 4 minggu penyimpanan. Kenaikan pH akan menyebabkan perubahan warna dari merah menjadi kuning kecoklatan, perubahan tersebut terjadi karena betasianin diubah menjadi betaxiantin (Rengku et al., 2017). Persentase perubahan kadar betasianin ekstrak pewarna dari bunga kenop selama penyimpanan disajikan dalam Tabel 2 .

Tabel 2. Persentase perubahan kadar betasianin ekstrak pewarna dari bunga kenop selama penyimpanan

\begin{tabular}{|c|c|c|c|}
\hline \multirow{2}{*}{ Perlakuan } & \multicolumn{2}{|c|}{ Kadar Betasianin (mg/100g) } & \multirow{2}{*}{ Penurunan $(\%)$} \\
\hline & Minggu ke-0 & Minggu ke-4 & \\
\hline $\mathrm{pH} 4 ;\left(4 \pm 2^{\circ} \mathrm{C}\right)$ & $374,90 \pm 0,00$ & $244,58 \pm 1,53$ & 34,76 \\
\hline pH 5; $\left(4 \pm 2^{\circ} \mathrm{C}\right)$ & $374,90 \pm 0,00$ & $235,71 \pm 2,02$ & 37,13 \\
\hline pH 6; $\left(4 \pm 2^{\circ} \mathrm{C}\right)$ & $374,90 \pm 0,00$ & $5,02 \pm 0,29$ & 98,66 \\
\hline pH $4 ;\left(28 \pm 2^{\circ} \mathrm{C}\right)$ & $374,90 \pm 0,00$ & $81,3 \pm 2,50$ & 78,31 \\
\hline pH 5; $\left(28 \pm 2^{\circ} \mathrm{C}\right)$ & $374,90 \pm 0,00$ & $45,34 \pm 1,76$ & 87,91 \\
\hline pH 6; $\left(28 \pm 2^{\circ} \mathrm{C}\right)$ & $374,90 \pm 0,00$ & $4,18 \pm 0,29$ & 98,88 \\
\hline
\end{tabular}

Tabel 2 menunjukkan adanya penurunan kadar betasianin untuk masingmasing perlakuan dari kontrol hingga minggu keempat. Perlakuan $\mathrm{pH}$ awal 4 dan penyimpanan suhu $4 \pm 1^{\circ} \mathrm{C}$ merupakan perlakuan yang menghasilkan penurunan kadar betasianin terkecil yaitu sebesar $34,76 \%$. Hal ini dikarenakan pada perlakuan tersebut pigmen betasianin pada ekstrak pewarna dari bunga kenop sedikit yang terdekomposisi dengan reaksi hidrolisis pada ikatan $\mathrm{N}=\mathrm{C}$, sehingga pigmen betasianin tidak mengalami dekomposisi menjadi asam betalamat dan siklo- DOPA 5-O-glikosida. Hal ini sesuai dengan pernyataan dari Herbach et al. (2006), yang menyatakan perubahan warna terjadi karena pigmen betasianin terdekomposisi dengan reaksi hidrolisis pada ikatan $\mathrm{N}=\mathrm{C}$, sehingga pigmen betasianin terdekomposisi menjadi asam betalamat (berwarna kuning) dan sikloDOPA 5-O-glikosida. Hal ini diperkuat dengan pernyataan dari Azeredo (2009), yang menyatakan panas atau asam menyebabkan 
terdegradasinya betasianin menjadi betasiantin yang dapat menyebabkan terjadinya isomerisasi, dekarboksilasi atau pembelahan yang berakibat terjadinya pengurangan warna merah ungu secara bertahap.

\section{Tingkat Kecerahan $\left(L^{*}\right) \quad$ Selama Penyimpanan}

Notasi dari $L^{*}$ menunjukkan cahaya pantul dengan spektrum warna dari hitam, abu-abu, hingga putih. Nilai dari koordinat $L^{*}$ yaitu 0 (hitam) hingga 100 (putih) (Bora et al., 2015). Nilai tingkat kecerahan $\left(L^{*}\right)$ kontrol pada ekstrak pewarna dari bunga kenop adalah sebesar 12,03.

Hasil analisis ragam menunjukkan bahwa perlakuan $\mathrm{pH}$ awal dan suhu berpengaruh sangat nyata $(\mathrm{P}<0,01)$ terhadap nilai tingkat kecerahan $\left(L^{*}\right)$ pada setiap minggunya. Interaksi kedua perlakuan berpengaruh sangat nyata $(\mathrm{P}<0,01)$ terhadap nilai tingkat kecerahan $\left(L^{*}\right)$ pada minggu ke1 dan 2. Data rata-rata nilai tingkat kecerahan $\left(L^{*}\right)$ ekstrak pewarna dari bunga kenop tiap minggunya disajikan pada Tabel 3.

Tabel 3. Nilai rata-rata tingkat kecerahan ( $\left.\mathrm{L}^{*}\right)$ ekstrak bunga kenop pada perlakuan $\mathrm{pH}$ awal dan suhu penyimpanan pada mingu ke-1 sampai minggu ke-4

\begin{tabular}{|c|c|c|c|c|}
\hline \multirow[b]{2}{*}{ Perlakuan } & \multicolumn{4}{|c|}{ Rata-rata nilai tingkat kecerahan $\left(\mathbf{L}^{*}\right) \pm \mathrm{SD}$} \\
\hline & Minggu 1 & Minggu 2 & Minggu 3 & Minggu 4 \\
\hline pH $4 ;\left(4 \pm 1^{\circ} \mathrm{C}\right)$ & $12,25 \pm 0,19 \mathrm{e}$ & $14,88 \pm 0,55 \mathrm{e}$ & $17,51 \pm 0,29 \mathrm{a}$ & $20,56 \pm 0,34 a$ \\
\hline pH 5; $\left(4 \pm 1^{\circ} \mathrm{C}\right)$ & $15,25 \pm 0,11 d$ & $16,42 \pm 0,28 \mathrm{~d}$ & $19,51 \pm 0,16 \mathrm{a}$ & $20,96 \pm 0,96$ \\
\hline pH 6; $\left(4 \pm 1^{\circ} \mathrm{C}\right)$ & $26,38 \pm 0,22 b$ & $23,99 \pm 0,61 b$ & $26,53 \pm 0,85 \mathrm{a}$ & $28,28 \pm 0,93$ \\
\hline pH $4 ;\left(28 \pm 2^{\circ} \mathrm{C}\right)$ & $14,84 \pm 0,26 \mathrm{~d}$ & $15,32 \pm 0,17 \mathrm{de}$ & $18,38 \pm 0,52 \mathrm{a}$ & $21,53 \pm 0,20$ \\
\hline pH 5; $\left(28 \pm 2^{\circ} \mathrm{C}\right)$ & $16,13 \pm 0,46 \mathrm{c}$ & $19,19 \pm 0,45 \mathrm{c}$ & $20,04 \pm 0,08 \mathrm{a}$ & $23,04 \pm 0,92$ \\
\hline pH 6; $\left(28 \pm 2^{\circ} \mathrm{C}\right)$ & $28,45 \pm 0,33 \mathrm{a}$ & $27,20 \pm 0,36 \mathrm{a}$ & $27,92 \pm 0,55 \mathrm{a}$ & $29,78 \pm 0,05 a$ \\
\hline
\end{tabular}

Keterangan: Angka yang diikuti huruf yang berbeda pada kolom yang sama menunjukkan berbeda nyata ( $\mathrm{p}<0,05)$.

Tabel 3 menunjukkan bahwa pada minggu ke-1 perlakuan $\mathrm{pH}$ awal 5 pada suhu $4 \pm 1^{\circ} \mathrm{C}$ memberikan nilai tingkat kecerahan (L*) yang tidak berbeda nyata dengan perlakuan $\mathrm{pH}$ awal 4 dengan penyimpanan suhu $28 \pm 2^{\circ} \mathrm{C}$, namun berbeda nyata dengan perlakuan lainnya. Pada minggu ke-2 perlakuan $\mathrm{pH}$ awal 4 pada suhu $4 \pm 1^{\circ} \mathrm{C}$ tidak berbeda nyata dengan perlakuan $\mathrm{pH}$ awal 4 pada suhu $28 \pm 2^{\circ} \mathrm{C}$, dan $\mathrm{pH}$ awal 5 pada suhu $4 \pm 1^{\circ} \mathrm{C}$ tidak berbeda nyata dengan perlakuan $\mathrm{pH}$ awal 4 pada suhu $28 \pm 2^{\circ} \mathrm{C}$, tetapi berpengaruh nyata dengan perlakuan lainnya. Pada minggu ke-3 dan 4 tidak berpengaruh nyata antar satu perlakuan dengan perlakuan lainnya. Perlakuan $\mathrm{pH}$ awal 4 dengan penyimpanan suhu $4 \pm 1^{\circ} \mathrm{C}$ menghasilkan ratarata nilai tingkat kecerahan $\left(\mathrm{L}^{*}\right)$ terendah pada setiap minggu penyimpanan. Hal ini disebabkan karena ekstrak bunga kenop pada $\mathrm{pH}$ awal 4 dan suhu $4 \pm 1^{\circ} \mathrm{C}$ mempunyai kadar betasianin lebih tinggi dibandingkan dengan perlakuan lainnya, yang telah dikonfirmasi dari hasil analisa kadar betasianin pada Tabel 1. Tingkat kecerahan $\left(\mathrm{L}^{*}\right)$ dari ekstrak semakin meningkat seiring dengan penurunan nilai tingkat kemerahan $\left(\mathrm{a}^{*}\right)$ (Tabel 5) dan peningkatan nilai tingkat kekuningan (b*) (Tabel 7). Menurut penelitian dari Sutrisno (1987), menyatakan 
bahwa suhu dan lama pemanasan menyebabkan terjadinya dekomposisi dan perubahan struktur pigmen, sehingga terjadi pemucatan yang menyebabkan nilai tingkat kecerahan semakin tinggi. Grafik kenaikan nilai tingkat kecerahan $\left(\mathrm{L}^{*}\right)$ dari kontrol hingga minggu ke-4 disajikan dalam Gambar 2.

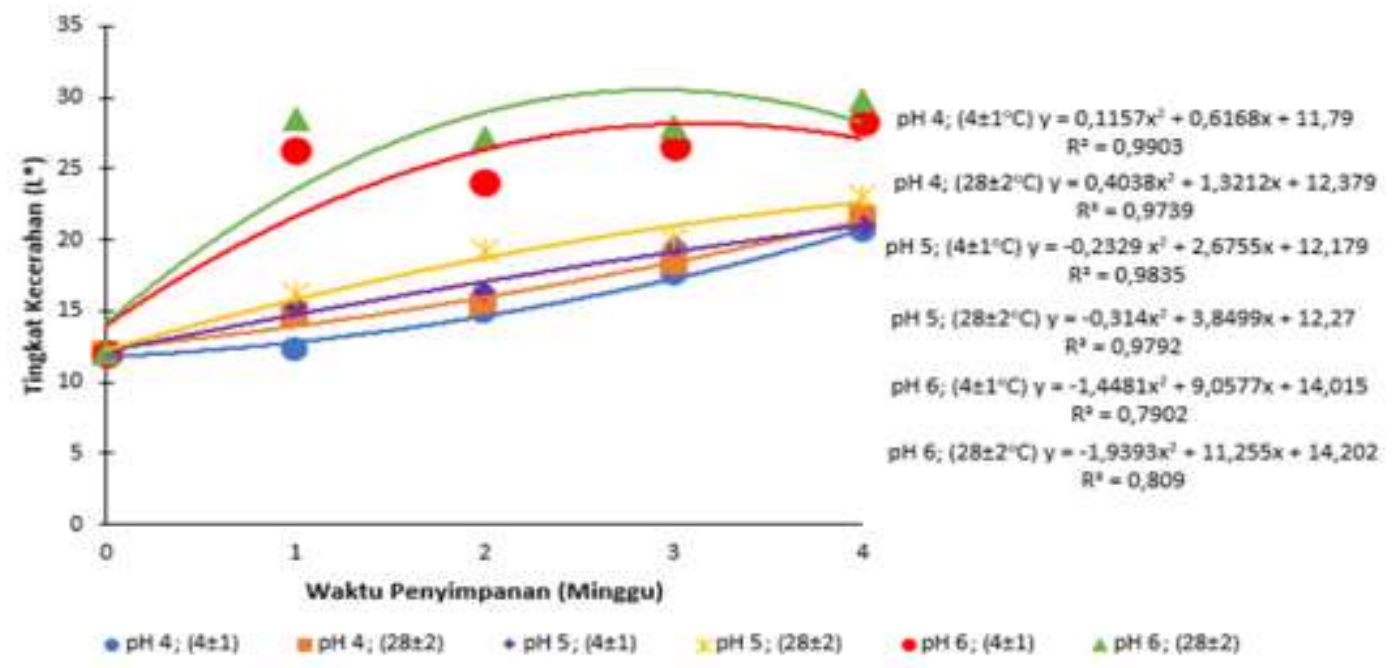

Gambar 2. Grafik kenaikan nilai tingkat kecerahan (L*) ekstrak pewarna dari bunga kenop selama penyimpanan pada perlakuan $\mathrm{pH}$ awal dan suhu

Gambar 2 menunjukkan model hubungan antara waktu penyimpanan dengan nilai tingkat kecerahan $\left(\mathrm{L}^{*}\right)$ mempunyai nilai nilai determinasi $\left(\mathrm{R}^{2}\right)$ berkisar antara 0,7902 sampai dengan 0,9903. Hal ini menunjukkan bahwa waktu penyimpanan berpengaruh terhadap nilai tingkat kecerahan $\left(\mathrm{L}^{*}\right)$ pada ekstrak pewarna bunga kenop. Nilai determinasi tertinggi sebesar 0,9903 diperoleh dari perlakuan $\mathrm{pH}$ awal 4 dengan penyimpanan suhu $4 \pm 1^{\circ} \mathrm{C}$. Ini menunjukkan bahwa 99,03\% nilai tingkat kecerahan $\left(\mathrm{L}^{*}\right)$ ekstrak pewarna dari bunga kenop dipengaruhi oleh waktu penyimpanan.

Gambar 2 menunjukkan kenaikan nilai tingkat kecerahan pada ekstrak pewarna dari bunga kenop. Semua persamaan memiliki nilai koefisien $b$ bernilai positif $(+)$. Ini menunjukkan korelasi antara nilai tingkat kecerahan $\left(\mathrm{L}^{*}\right)$ dengan waktu penyimpanan berbanding lurus, artinya semakin lama waktu penyimpanan maka semakin tinggi nilai tingkat kecerahan $\left(\mathrm{L}^{*}\right)$ dari ekstrak pewarna dari bunga kenop dan sebaliknya. Persamaan regresi pada perlakuan $\mathrm{pH}$ awal 4 dan penyimpanan pada suhu $4 \pm 1^{\circ} \mathrm{C}$ memiliki koefisien persamaan lebih kecil dibandingkan dengan persamaan pada perlakuan lainnya. Ini menunjukkan kenaikan nilai tingkat kecerahan $\left(\mathrm{L}^{*}\right)$ terkecil diperoleh pada perlakuan $\mathrm{pH}$ awal 4 dan penyimpanan pada suhu $4 \pm 1^{\circ} \mathrm{C}$. Pada perlakuan $\mathrm{pH}$ awal 6 dan suhu $28 \pm 2^{\circ} \mathrm{C}$ memiliki koefisien persamaan lebih besar dibandingkan dengan persamaan pada perlakuan lainnya. Hal ini berarti nilai tingkat kecerahan ( $\left.\mathrm{L}^{*}\right)$ pada ekstrak bunga kenop paling tidak stabil pada perlakuan $\mathrm{pH}$ awal 6 dan suhu $28 \pm 2^{\circ} \mathrm{C}$ dibandingkan dengan perlakuan lainnya. Hal ini membuktikan bahwa penyimpanan dengan perlakuan $\mathrm{pH}$ awal 4 dengan suhu $4 \pm 1^{\circ} \mathrm{C}$ menyebabkan pigmen betasianin yang merupakan senyawa antioksidan mengalami paling sedikit kerusakan, kerusakan paling besar terjadi pada perlakuan $\mathrm{pH} 6$ dengan suhu $28 \pm 2^{\circ} \mathrm{C}$. Persentase perubahan nilai tingkat kecerahan (L*) ekstrak pewarna dari bunga kenop selama penyimpanan disajikan dalam Tabel 4 
Tabel 4. Persentase perubahan nilai tingkat kecerahan (L*) ekstrak pewarna dari bunga kenop selama penyimpanan

\begin{tabular}{|c|c|c|c|}
\hline \multirow[t]{2}{*}{ Perlakuan } & \multicolumn{2}{|c|}{ Nilai tingkat kecerahan (L*) } & \multirow[t]{2}{*}{ Kenaikan (\%) } \\
\hline & Minggu ke-0 & Minggu ke-4 & \\
\hline pH 4; $\left(4 \pm 1^{\circ} \mathrm{C}\right)$ & $12,03 \pm 0,00$ & $20,56 \pm 0,34$ & 34,76 \\
\hline pH $5 ;\left(4 \pm 1^{\circ} \mathrm{C}\right)$ & $12,03 \pm 0,00$ & $20,96 \pm 0,96$ & 37,13 \\
\hline pH 6; $\left(4 \pm 1^{\circ} \mathrm{C}\right)$ & $12,03 \pm 0,00$ & $28,28 \pm 0,93$ & 98,66 \\
\hline pH 4; $\left(28 \pm 2^{\circ} \mathrm{C}\right)$ & $12,03 \pm 0,00$ & $21,53 \pm 0,20$ & 78,31 \\
\hline pH 5; $\left(28 \pm 2^{\circ} \mathrm{C}\right)$ & $12,03 \pm 0,00$ & $23,04 \pm 0,92$ & 87,91 \\
\hline pH 6; $\left(28 \pm 2^{\circ} \mathrm{C}\right)$ & $12,03 \pm 0,00$ & $29,78 \pm 0,05$ & 98,88 \\
\hline
\end{tabular}

Tabel 4 menunjukkan adanya kenaikan nilai tingkat kecerahan $\left(\mathrm{L}^{*}\right)$ untuk masingmasing perlakuan dari kontrol hingga minggu keempat. Perlakuan $\mathrm{pH} 4$ dan suhu $4 \pm 1^{\circ} \mathrm{C}$ merupakan perlakuan yang mengakibatkan kenaikan nilai tingkat kecerahan $\left(\mathrm{L}^{*}\right)$ terkecil yaitu sebesar 70,91\%. Hal ini menunjukkan bahwa nilai tingkat kecerahan pada ekstrak pewarna bunga kenop paling stabil pada perlakuan tesebut. Perlakuan $\mathrm{pH} 6$ dan suhu $28 \pm 2^{\circ} \mathrm{C}$ menunjukkan kenaikan nilai tingkat kecerahan (L*) terbesar dibandingkan perlakuan lainnya yaitu sebesar $147,55 \%$. Hal ini menunjukkan bahwa nilai tingkat kecerahan $\left(\mathrm{L}^{*}\right)$ pada ekstrak pewarna dari bunga kenop paling tidak stabil pada perlakuan tersebutPeningkatan nilai tingkat kecerahan juga menunjukkan terjadinya kerusakan pada betasianin (Herbach et al., 2006). Kenaikan nilai tingkat kecerahan diakibatkan oleh adanya dekomposisi struktur pigmen betasianin ekstrak daun darah oleh panas sehingga terjadi pemucatan dan menyebabkan nilai tingkat kecerahan semakin terang (Khuluq et al., 2007).

\section{Tingkat Kemerahan $\quad\left(a^{*}\right)$ Selama Penyimpanan}

Notasi a* menyatakan warna kromatik campuran dari merah hingga hijau dan diagram warna akan menyatakan warna merah apabila nilai dari a* adalah positif (0 sampai 100) sedangkan diagram akan menunjukkan warna hijau apabila nilai dari $\mathrm{a}^{*}$ adalah negatif (0 sampai -100) (Bora et al., 2015). Nilai tingkat kemerahan (a*) kontrol pada ekstrak perwarna dari bunga kenop adalah sebesar 14,47.

Analisis ragam menunjukkan bahwa perlakuan $\mathrm{pH}$ awal berpengaruh sangat nyata $(\mathrm{P}<0,01)$ terhadap nilai tingkat kemerahan (a*) pada setiap minggunya. Perlakuan suhu berpengaruh sangat nyata $(\mathrm{P}<0,01)$ terhadap nilai tingkat kemerahan $\left(\mathrm{a}^{*}\right)$ pada minggu ke3 dan 4. Interaksi kedua perlakuan berpengaruh nyata $(\mathrm{P}<0,05)$ terhadap nilai tingkat kemerahan $\left(a^{*}\right)$ pada minggu ke-2. Nilai rata-rata kemerahan $\left(a^{*}\right)$ ekstrak pewarna dari bunga kenop pada perlakuan $\mathrm{pH}$ awal dan suhu penyimpanan disajikan dalam Tabel 5.

Tabel 5 menunjukkan bahwa interaksi antar perlakuan $\mathrm{pH}$ awal dan suhu pada minggu ke-1, 3, dan 4 tidak memberikan nilai tingkat kemerahan $\left(\mathrm{a}^{*}\right)$ yang berbeda nyata antar satu perlakuan dengan perlakuan lainnya. Pada minggu ke-2 perlakuan $\mathrm{pH} 4$ pada penyimpanan suhu $4 \pm 1^{\circ} \mathrm{C}$ dan suhu $28 \pm 2^{\circ} \mathrm{C}$ tidak berbeda nyata dengan perlakuan pH 5 pada suhu $4 \pm 1^{\circ} \mathrm{C}$ dan suhu 
$28 \pm 2^{\circ} \mathrm{C}$, tetapi berbeda nyata dengan perlakuan $\mathrm{pH} 6$ pada penyimpanan suhu $4 \pm 1^{\circ} \mathrm{C}$ dan suhu $28 \pm 2^{\circ} \mathrm{C}$. Perlakuan $\mathrm{pH}$ awal 4 dan suhu $4 \pm 1^{\circ} \mathrm{C}$ menghasilkan rata-rata nilai tingkat kemerahan $\left(a^{*}\right)$ tertinggi pada minggu ke-2 penyimpanan. Hal ini disebabkan ekstrak bunga kenop pada $\mathrm{pH}$ awal 4 dan suhu $4 \pm 1^{\circ} \mathrm{C}$ mempunyai kadar betasianin lebih tinggi dibandingkan dengan perlakuan lainnya, yang telah dikonfirmasi dari hasil analisa kadar betasianin pada Tabel 1. Tingkat kemerahan $\left(a^{*}\right)$ dari ekstrak semakin menurun seiring dengan peningkatan nilai tingkat kecerahan (L*) (Tabel 3) dan peningkatan nilai tingkat kekuningan (L*) (Tabel 7).

Tabel 5. Nilai rata-rata tingkat kemerahan ( $\left.\mathrm{a}^{*}\right)$ ekstrak bunga kenop pada perlakuan $\mathrm{pH}$ awal dan suhu penyimpanan pada mingu ke-1 sampai minggu ke-4

\begin{tabular}{|c|c|c|c|c|}
\hline \multirow[b]{2}{*}{ Perlakuan } & \multicolumn{4}{|c|}{ Rata-rata nilai tingkat kemerahan $\left(a^{*}\right) \pm$ SD } \\
\hline & Minggu 1 & Minggu 2 & Minggu 3 & Minggu 4 \\
\hline pH 4; $\left(4 \pm 1^{\circ} \mathrm{C}\right)$ & $8,67 \pm 0,58 \mathrm{a}$ & $7,99 \pm 0,03 \mathrm{a}$ & $7,60 \pm 0,21 \mathrm{a}$ & $7,03 \pm 0,36 \mathrm{a}$ \\
\hline pH 5; $\left(4 \pm 1^{\circ} \mathrm{C}\right)$ & $8,27 \pm 0,59 \mathrm{a}$ & $7,40 \pm 0,20 \mathrm{a}$ & $7,20 \pm 0,22 \mathrm{a}$ & $6,62 \pm 0,24 \mathrm{a}$ \\
\hline pH 6; $\left(4 \pm 1^{\circ} \mathrm{C}\right)$ & $4,22 \pm 0,31 \mathrm{a}$ & $4,19 \pm 0,31 b$ & $3,83 \pm 0,13 a$ & $2,82 \pm 0,13 a$ \\
\hline pH $4 ;\left(28 \pm 2^{\circ} \mathrm{C}\right)$ & $8,57 \pm 0,25 \mathrm{a}$ & $7,89 \pm 0,54 \mathrm{a}$ & $6,75 \pm 0,29 a$ & $6,47 \pm 0,39 a$ \\
\hline pH $5 ;\left(28 \pm 2^{\circ} \mathrm{C}\right)$ & $8,15 \pm 0,33 \mathrm{a}$ & $7,63 \pm 0,54 a$ & $6,45 \pm 0,13 a$ & $6,12 \pm 0,13 a$ \\
\hline pH 6; $\left(28 \pm 2^{\circ} \mathrm{C}\right)$ & $3,59 \pm 0,42 \mathrm{a}$ & $3,24 \pm 0,36 b$ & $3,05 \pm 0,25 \mathrm{a}$ & $2,16 \pm 0,12 \mathrm{a}$ \\
\hline
\end{tabular}

Keterangan: Angka yang diikuti huruf yang berbeda pada kolom yang sama menunjukkan berbeda nyata $(p<0,05)$.

Nilai tingkat kemerahan (a*) untuk semua perlakuan memiliki nilai positif. Hal ini dikarenakan pigmen warna ekstrak bunga kenop mengandung senyawa betasianin yang memiliki warna kemerahan. Intensitas warna lebih stabil ketika disimpan di suhu kulkas dibanding suhu ruang, dengan proses pendinginan di suhu kulkas akan mengurangi penguapan air, memperlambat reaksi kimiawi sel, dan meminimalkan pertumbuhan mikroba (Sumonsiri dan Sheryl, 2014). Grafik penurunan nilai tingkat kemerahan (a*) ekstrak pewarna dari bunga kenop untuk masing-masing perlakuan selama penyimpanan disajikan dalam Gambar 3.

Gambar 3 menunjukkan model hubungan antara waktu penyimpanan dengan nilai tingkat kemerahan $\left(a^{*}\right)$ mempunyai nilai nilai determinasi $\left(\mathrm{R}^{2}\right)$ berkisar antara 0,8568 sampai dengan 0,9393. Hal ini menunjukkan bahwa waktu penyimpanan berpengaruh terhadap warna kemerahan $\left(\mathrm{a}^{*}\right)$ pada ekstrak pewarna bunga kenop. Nilai determinasi tertinggi sebesar 0,9393 diperoleh dari perlakuan $\mathrm{pH}$ awal 4 dengan penyimpanan suhu $28 \pm 2^{\circ} \mathrm{C}$. Ini menunjukkan bahwa 93,93\% nilai tingkat kemerahan( $\left.a^{*}\right)$ ekstrak pewarna dari bunga kenop dipengaruhi oleh waktu penyimpanan.

Gambar 3 menunjukkan bahwa semua persamaan memiliki nilai koefisien $b$ bernilai negatif (-). Ini menunjukkan korelasi antara nilai tingkat kemerahan $\left(a^{*}\right)$ dengan waktu penyimpanan berbanding terbalik, artinya semakin lama waktu penyimpanan maka semakin rendah nilai tingkat kemerahan $\left(\mathrm{a}^{*}\right)$ dari ekstrak pewarna dari bunga kenop dan sebaliknya. Persamaan regresi pada perlakuan $\mathrm{pH}$ awal 4 dan penyimpanan pada suhu $4 \pm 1^{\circ} \mathrm{C}$ memiliki koefisien persamaan 
lebih kecil dibandingkan dengan persamaan pada perlakuan lainnya.

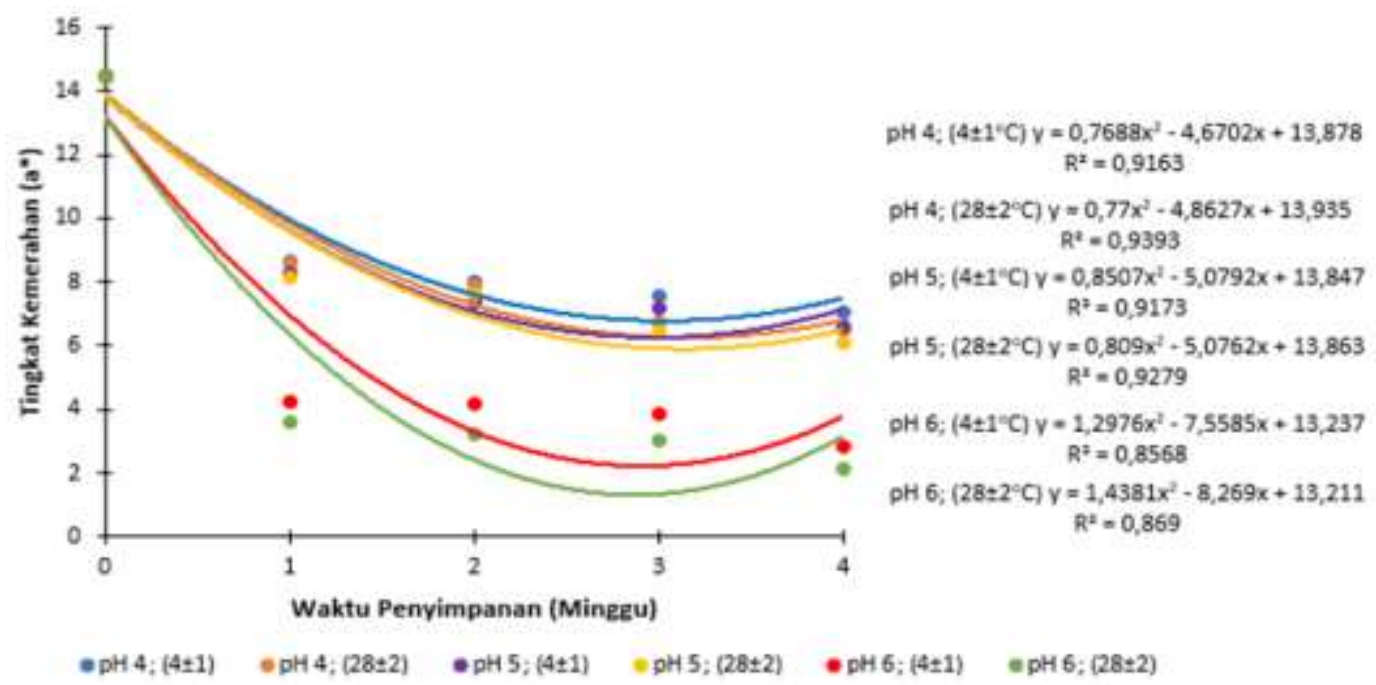

Gambar 3. Grafik penurunan nilai tingkat kemerahan (a*) ekstrak pewarna dari bunga kenop selama penyimpanan pada perlakuan $\mathrm{pH}$ awal dan suhu

Ini menunjukkan penurunan nilai tingkat kemerahan $\left(\mathrm{a}^{*}\right)$ terkecil diperoleh pada perlakuan $\mathrm{pH}$ awal 4 dan penyimpanan pada suhu $4 \pm 1^{\circ} \mathrm{C}$. Pada perlakuan $\mathrm{pH}$ awal 6 dan suhu $28 \pm 2^{\circ} \mathrm{C}$ memiliki koefisien persamaan lebih besar dibandingkan dengan persamaan pada perlakuan lainnya. Hal ini berarti nilai tingkat kemerahan $\left(\mathrm{a}^{*}\right)$ pada ekstrak bunga kenop paling tidak stabil pada perlakuan $\mathrm{pH}$ awal 6 dan suhu $28 \pm 2^{\circ} \mathrm{C}$ dibandingkan dengan perlakuan lainnya. Hal ini dikarenakan pada perlakuan $\mathrm{pH}$ awal 4 dan suhu $4 \pm 1^{\circ} \mathrm{C}$ pigmen betasianin yang berwarna merah paling sedikit mengalami perubahan struktur menjadi betaxiantin selama proses penyimpanan. Persentase perubahan nilai tingkat kemerahan $\left(\mathrm{a}^{*}\right)$ ekstrak pewarna dari bunga kenop selama penyimpanan disajikan dalam Tabel 6.

Tabel 6. Persentase perubahan nilai tingkat kemerahan ( $\left.a^{*}\right)$ ekstrak pewarna dari bunga kenop selama penyimpanan

\begin{tabular}{|c|c|c|c|}
\hline \multirow{2}{*}{ Perlakuan } & \multicolumn{2}{|c|}{ Nilai tingkat kemerahan (a*) } & \multirow{2}{*}{ Penurunan $(\%)$} \\
\hline & Minggu ke-0 & Minggu ke-4 & \\
\hline $\mathrm{pH} 4 ;\left(4 \pm 1^{\circ} \mathrm{C}\right)$ & $14,47 \pm 0,00$ & $7,03 \pm 0,36$ & 51,42 \\
\hline pH 5; $\left(4 \pm 1^{\circ} \mathrm{C}\right)$ & $14,47 \pm 0,00$ & $6,62 \pm 0,24$ & 54,23 \\
\hline pH $6 ;\left(4 \pm 1^{\circ} \mathrm{C}\right)$ & $14,47 \pm 0,00$ & $2,82 \pm 0,13$ & 80,49 \\
\hline pH $4 ;\left(28 \pm 2^{\circ} \mathrm{C}\right)$ & $14,47 \pm 0,00$ & $6,47 \pm 0,39$ & 55,31 \\
\hline pH $5 ;\left(28 \pm 2^{\circ} \mathrm{C}\right)$ & $14,47 \pm 0,00$ & $6,12 \pm 0,13$ & 57,68 \\
\hline pH 6; $\left(28 \pm 2^{\circ} \mathrm{C}\right)$ & $14,47 \pm 0,00$ & $2,16 \pm 0,12$ & 85,1 \\
\hline
\end{tabular}


Tabel 6 menunjukkan adanya penurunan nilai tingkat kemerahan (a*) untuk masing-masing perlakuan dari kontrol hingga minggu keempat. Perlakuan $\mathrm{pH} 4$ dengan penyimpanan suhu $4 \pm 1^{\circ} \mathrm{C}$ menunjukkan penurunan nilai tingkat kemerahan paling kecil yaitu $61,85 \%$ sedangkan penurunan nilai tingkat kemerahan terbesar terdapat pada perlakuan $\mathrm{pH} 6$ dan suhu $28 \pm 2^{\circ} \mathrm{C}$ yaitu $102,23 \%$. Hal ini menunjukkan bahwa pigmen betasianin yang terdapat dalam ekstrak pewarna dari bunga kenop memiliki stabilitas paling baik pada perlakuan tersebut, ini dikarenakan pigmen betasianin lebih stabil pada $\mathrm{pH}$ rendah dan suhu dingin sehingga nilai tingkat kemerahan $\left(\mathrm{a}^{*}\right)$ sedikit mengalami penurunan. Pigmen betasianin menjadi semakin tidak stabil ditandai dengan perubahan warna ekstrak yang berwarna merah bertahap menjadi kuning dipengaruhi oleh pH (Asra et al., 2020). Kenaikan pH akan menyebabkan perubahan warna dari merah menjadi kuning kecoklatan, perubahan tersebut terjadi karena betasianin diubah menjadi betaxiantin (Rengku et al., 2017)

Tingkat Kekuningan $\left(a^{*}\right)$ Selama

\section{Penyimpanan}

Nilai $b^{*}$ pada uji intensitas warna merupakan indikator warna dari biru hingga kuning. Notasi $b^{*}$ merupakan notasi dari warna kromatik campuran dari warna biru hingga kuning dan nilai $b^{*}$ yang positif $(0$ sampai 100) menunjukkan warna kuning sedangkan nilai negatif dari b* (0 sampai 100) menunjukkan warna biru (Bora et al., 2015). Nilai tingkat kekuningan kontrol pada ekstrak pewarna dari bunga kenop adalah sebesar 3,66. Analisis ragam menunjukkan bahwa perlakuan $\mathrm{pH}$ awal berpengaruh sangat nyata $(\mathrm{P}<0,01)$ terhadap nilai tingkat kekuningan $\left(b^{*}\right)$ pada setiap minggunya. Perlakuan suhu berpengaruh sangat nyata $(\mathrm{P}<0,01)$ terhadap nilai tingkat kekuningan (b*) pada minggu ke-1 dan 3, tetapi hanya berpengaruh nyata $(\mathrm{P}<0,05)$ terhadap nilai tingkat kekuningan $\left(b^{*}\right)$ pada minggu ke-4. Interaksi antar perlakuan berpengaruh sangat nyata $(\mathrm{P}<0,01)$ terhadap nilai tingkat kekuningan $\left(b^{*}\right)$ pada minggu ke-3 dan 4. Rata-rata nilai tingkat kekuningan $\left(b^{*}\right)$ ekstrak pewarna dari bunga kenop pada perlakuan $\mathrm{pH}$ dan suhu selama penyimpanan disajikan dalam Tabel 7.

Tabel 7. Nilai rata-rata tingkat kekuningan ( $\left.\mathrm{b}^{*}\right)$ ekstrak bunga kenop pada perlakuan $\mathrm{pH}$ awal dan suhu penyimpanan pada mingu ke-1 sampai minggu ke-4

\section{Rata-rata nilai tingkat kekuningan $\left(b^{*}\right) \pm S D$}

\begin{tabular}{|c|c|c|c|c|}
\hline Perlakuan & Minggu 1 & Minggu 2 & Minggu 3 & Minggu 4 \\
\hline $\mathrm{pH} 4 ;\left(4 \pm 1^{\circ} \mathrm{C}\right)$ & $3,75 \pm 0,16 \mathrm{a}$ & $5,4 \pm 0,79 a$ & $5,52 \pm 0,32 \mathrm{~d}$ & $6,12 \pm 0,24 \mathrm{e}$ \\
\hline pH 5; $\left(4 \pm 1^{\circ} \mathrm{C}\right)$ & $4,4 \pm 0,14 \mathrm{a}$ & $5,74 \pm 0,46 a$ & $6,69 \pm 0,31 \mathrm{c}$ & $6,89 \pm 0,28 \mathrm{de}$ \\
\hline pH $6 ;\left(4 \pm 1^{\circ} \mathrm{C}\right)$ & $7,71 \pm 0,28 \mathrm{a}$ & $7,91 \pm 0,22 \mathrm{a}$ & $11,77 \pm 0,61 \mathrm{a}$ & $13,57 \pm 0,36 \mathrm{a}$ \\
\hline pH 4; $\left(28 \pm 2^{\circ} \mathrm{C}\right)$ & $4,85 \pm 0,37 \mathrm{a}$ & $5,97 \pm 0,25 \mathrm{a}$ & $7,26 \pm 0,23 \mathrm{c}$ & $7,68 \pm 0,28 \mathrm{~cd}$ \\
\hline pH 5; $\left(28 \pm 2^{\circ} \mathrm{C}\right)$ & $5,45 \pm 0,33 a$ & $6,1 \pm 0,20 \mathrm{a}$ & $9,34 \pm 0,22 b$ & $9,77 \pm 0,30 b$ \\
\hline pH 6; $\left(28 \pm 2^{\circ} \mathrm{C}\right)$ & $8,79 \pm 0,15 \mathrm{a}$ & $7,8 \pm 0,71 \mathrm{a}$ & $10,15 \pm 0,15 b$ & $8,13 \pm 0,26 \mathrm{c}$ \\
\hline
\end{tabular}

Keterangan: Angka yang diikuti huruf yang berbeda pada kolom yang sama menunjukkan berbeda nyata $(\mathrm{p}<0,05)$.

Tabel 7 menunjukkan bahwa interaksi

antar perlakuan $\mathrm{pH}$ awal dan suhu pada 
minggu ke-1 dan ke-2 tidak memberikan nilai tingkat kekuningan $\left(b^{*}\right)$ yang berbeda nyata antar satu perlakuan dengan perlakuan lainnya. Pada minggu ke-3 perlakuan $\mathrm{pH}$ awal 5 dengan penyimpanan suhu $4 \pm 1^{\circ} \mathrm{C}$ tidak berbeda nyata dengan perlakuan $\mathrm{pH}$ awal 4 pada suhu $28 \pm 2^{\circ} \mathrm{C}$, serta perlakuan $\mathrm{pH}$ awal 5 pada suhu $28 \pm 2^{\circ} \mathrm{C}$ tidak berbeda nyata dengan perlakuan $\mathrm{pH}$ awal 6 pada suhu $28 \pm 2^{\circ} \mathrm{C}$, tetapi berbeda nyata dengan perlakuan lainnya. Pada minggu ke-4 perlakuan $\mathrm{pH}$ awal 4 pada suhu $4 \pm 1^{\circ} \mathrm{C}$ tidak berbeda nyata dengan perlakuan $\mathrm{pH}$ awal 5 pada suhu $4 \pm 1^{\circ} \mathrm{C}$, serta perlakuan $\mathrm{pH}$ awal 4 pada suhu $28 \pm 2^{\circ} \mathrm{C}$ tidak berbeda nyata dengan perlakuan $\mathrm{pH}$ awal 5 pada suhu $28 \pm 22^{\circ} \mathrm{C}$, tetapi berbeda nyata dengan perlakuan lainnya. Perlakuan $\mathrm{pH}$ awal 4 dan suhu $4 \pm 1^{\circ} \mathrm{C}$ menghasilkan rata-rata nilai tingkat kekuningan $\left(\mathrm{b}^{*}\right)$ terendah pada minggu ke-3 dan 4 penyimpanan dan berbeda nyata dengan perlakuan lainnya. Hal ini disebabkan ekstrak bunga kenop pada $\mathrm{pH}$ awal 4 dan suhu $4 \pm 1^{\circ} \mathrm{C}$ mempunyai kadar betasianin lebih tinggi dibandingkan dengan perlakuan lainnya, yang telah dikonfirmasi dari hasil analisa kadar betasianin pada Tabel 1. Tingkat kekuningan $\left(b^{*}\right)$ dari ekstrak semakin meningkat seiring dengan penurunan nilai tingkat kemerahan $\left(\mathrm{a}^{*}\right)$ (Tabel 5) dan peningkatan nilai tingkat kecerahan (L*) (Tabel 3). Grafik kenaikan nilai tingkat kekuningan $\left(b^{*}\right)$ ekstrak pewarna dari bunga kenop pada masingmasing perlakuan selama penyimpanan disajikan pada Gambar 4.

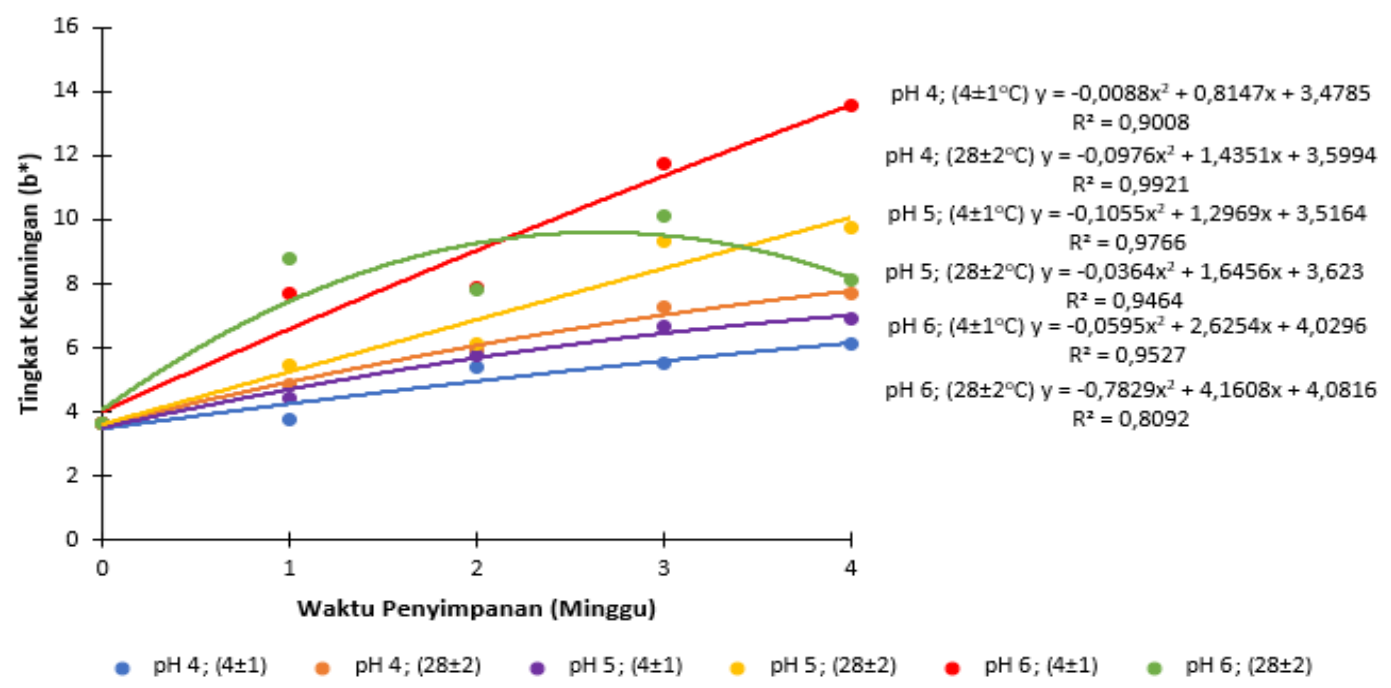

Gambar 4. Grafik kenaikan nilai tingkat kekuningan ( $\left.b^{*}\right)$ ekstrak pewarna dari bunga kenop selama penyimpanan pada perlakuan $\mathrm{pH}$ awal dan suhu

Gambar 4 menunjukkan model hubungan antara waktu penyimpanan dengan nilai tingkat kekuningan $\left(b^{*}\right)$ mempunyai nilai nilai determinasi $\left(\mathrm{R}^{2}\right)$ berkisar antara 0,8092 sampai dengan 0,9921. Hal ini menunjukkan bahwa waktu penyimpanan berpengaruh terhadap nilai tingkat kekuningan $\left(b^{*}\right)$ pada ekstrak pewarna bunga kenop. Nilai determinasi tertinggi sebesar 0,9921 diperoleh dari perlakuan $\mathrm{pH}$ awal 4 dengan penyimpanan suhu $28 \pm 2^{\circ} \mathrm{C}$. Ini menunjukkan bahwa 99,21\% nilai tingkat kekuningan $\left(b^{*}\right)$ ekstrak pewarna dari bunga kenop dipengaruhi oleh waktu penyimpanan. Gambar 4 menunjukkan kenaikan nilai tingkat kekuningan $\left(b^{*}\right)$ pada ekstrak pewarna dari bunga kenop. Semua persamaan memiliki nilai koefisien b bernilai positif $(+)$. Ini menunjukkan korelasi antara nilai tingkat kekuningan $\left(b^{*}\right)$ dengan waktu penyimpanan berbanding lurus, artinya semakin lama waktu penyimpanan maka semakin tinggi 
nilai tingkat kekuningan $\left(b^{*}\right)$ dari ekstrak pewarna dari bunga kenop dan sebaliknya. Persamaan regresi pada perlakuan $\mathrm{pH}$ awal 4 dan penyimpanan pada suhu $4 \pm 1^{\circ} \mathrm{C}$ memiliki koefisien persamaan lebih kecil dibandingkan dengan persamaan pada perlakuan lainnya. Ini menunjukkan kenaikan nilai tingkat kekuningan $\left(b^{*}\right)$ terkecil diperoleh pada perlakuan $\mathrm{pH}$ awal 4 dan penyimpanan pada suhu $4 \pm 1^{\circ} \mathrm{C}$. Pada perlakuan $\mathrm{pH}$ awal 6 dan suhu $28 \pm 2^{\circ} \mathrm{C}$ memiliki koefisien persamaan lebih besar dibandingkan dengan persamaan pada perlakuan lainnya. Hal ini berarti nilai tingkat kekuningan $\left(b^{*}\right)$ dari ekstrak bunga kenop paling tidak stabil pada perlakuan $\mathrm{pH}$ awal 6 dan suhu $28 \pm 2^{\circ} \mathrm{C}$ dibandingkan dengan perlakuan lainnya. Hal ini dikarenakan pada perlakuan $\mathrm{pH}$ awal 4 dengan penyimpanan pada suhu $4 \pm 1^{\circ} \mathrm{C}$ pigmen betasianin sedikit yang berubah bentuk menjadi asam betalamat, sehingga ekstrak tidak mengalami perubahan warna menjadi kekuningan. Persentase perubahan nilai tingkat kekuningan $\left(b^{*}\right)$ ekstrak pewarna dari bunga kenop selama penyimpanan disajikan dalam Tabel 8.

Tabel 8. Persentase perubahan nilai tingkat kekuningan $\left(b^{*}\right)$ ekstrak pewarna dari bunga kenop selama penyimpanan

\begin{tabular}{|c|c|c|c|}
\hline \multirow{2}{*}{ Perlakuan } & \multicolumn{2}{|c|}{ Nilai tingkat kekuningan (b*) } & \multirow{2}{*}{ Kenaikan (\%) } \\
\hline & Minggu ke-0 & Minggu ke-4 & \\
\hline pH 4; $\left(4 \pm 1^{\circ} \mathrm{C}\right)$ & $3,66 \pm 0,00$ & $6,12 \pm 0,24$ & 67,21 \\
\hline pH 5; $\left(4 \pm 1^{\circ} \mathrm{C}\right)$ & $3,66 \pm 0,00$ & $6,89 \pm 0,28$ & 88,25 \\
\hline pH 6; $\left(4 \pm 1^{\circ} \mathrm{C}\right)$ & $3,66 \pm 0,00$ & $13,57 \pm 0,36$ & 270,77 \\
\hline pH 4; $\left(28 \pm 2^{\circ} \mathrm{C}\right)$ & $3,66 \pm 0,00$ & $7,68 \pm 0,28$ & 109,84 \\
\hline pH 5; $\left(28 \pm 2^{\circ} \mathrm{C}\right)$ & $3,66 \pm 0,00$ & $9,77 \pm 0,30$ & 166,85 \\
\hline pH 6; $\left(28 \pm 2^{\circ} \mathrm{C}\right)$ & $3,66 \pm 0,00$ & $8,13 \pm 0,26$ & 122,13 \\
\hline
\end{tabular}

Tabel 8 menunjukkan adanya kenaikan nilai tingkat kekuningan $\left(b^{*}\right)$ masing-masing perlakuan dari kontrol hingga minggu keempat. Kenaikan nilai tingkat kekuningan pada perlakuan $\mathrm{pH}$ awal 4 dengan penyimpanan suhu $4 \pm 1^{\circ} \mathrm{C}$ menunjukkan persentase kenaikan paling kecil yaitu sebesar $67,21 \%$ sedangkan persentase kenaikan nilai tingkat kekuningan terbesar terdapat pada perlakuan $\mathrm{pH}$ awal 6 dengan penyimpanan suhu $4 \pm 1^{\circ} \mathrm{C}$ yaitu sebesar $270,77 \%$. Hal ini menunjukkan bahwa ekstrak pewarna dari bunga kenop lebih stabil pada perlakuan penyimpanan dengan $\mathrm{pH}$ awal 4 dan suhu $4 \pm 1^{\circ} \mathrm{C}$, hal ini dibuktikan dengan pigmen betasianin yang memiliki warna merah paling sedikit mengalami kerusakan sehingga tidak mengalami perubahan warna menjadi kuning. Peningkatan intensitas warna kuning menunjukkan penurunan konsentrasi betasianin, hal ini dikarenakan betasianin memberikan pengaruh warna merah yang lebih besar dibandingkan warna kuning pada ekstrak selain menunjukkan peningkatan kerusakan betasianin (Khuluq et al., 2007). Hal ini sesuai dengan penelitian Zakharova dan Petrova (2000), yang menyatakan bahwa degradasi pigmen betasianin bersifat reversibel dan diikuti oleh sintesis pigmen 
kuning betaxantin dalam grup amina dengan peningkatan tingkat kekuningan $\left(b^{*}\right)$ disertai penurunan tingkat kemerahan $\left(\mathrm{a}^{*}\right)$. Kenaikan nilai tingkat kekuningan $\left(b^{*}\right)$ disebabkan karena adanya perubahan warna karena pigmen betasianin terdekomposisi dengan reaksi hidrolisis pada ikatan $\mathrm{N}=\mathrm{C}$, sehingga pigmen betasianin terdekomposisi menjadi asam betalamat (berwarna kuning) dan sikloDOPA 5-O-glikosida (Herbach et al., 2006).

\section{KESIMPULAN DAN SARAN}

\section{Kesimpulan}

Berdasarkan penelitian yang telah dilakukan maka dapat disimpulkan beberapa hal sebagai berikut:

1. Perlakuan $\mathrm{pH}$ awal berpengaruh sangat nyata terhadap kadar betasianin, nilai tingkat kecerahan $\left(\mathrm{L}^{*}\right)$, nilai tingkat kemerahan $\left(a^{*}\right)$, dan nilai tingkat kekuningan $\left(b^{*}\right)$ selama penyimpanan. Perlakuan suhu berpengaruh sangat nyata terhadap kadar betasianin dan nilai tingkat kecerahan $\left(\mathrm{L}^{*}\right)$ selama penyimpanan, dan berpengaruh sangat nyata terhadap nilai tingkat kemerahan (a*) pada minggu ke-3 dan 4, serta berpengaruh sangat nyata terhadap nilai tingkat kekuningan $\left(b^{*}\right)$ ada minggu ke1 dan 3, hanya berpengaruh nyata terhadap nilai tingkat kekuningan $\left(b^{*}\right)$ pada minggu ke-4. Interaksi kedua perlakuan berpengaruh sangat nyata pada setiap minggunya terhadap kadar betasianin, berpengaruh sangat nyata nilai tingkat kecerahan $\left(\mathrm{L}^{*}\right)$ pada minggu ke-1 dan 2, hanya berpengaruh nyata terhadap nilai tingkat kemerahan $\left(\mathrm{a}^{*}\right)$ pada minggu ke-2, serta berpengaruh sangat nyata terhadap nilai tingkat kekuningan $\left(b^{*}\right)$ pada minggu ke-3 dan 4.

2. Ekstrak pewarna dari bunga kenop paling stabil pada perlakuan $\mathrm{pH}$ awal 4 dan suhu $\left(4 \pm 1^{\circ} \mathrm{C}\right)$ selama penyimpanan, dengan penurunan kadar betasianin sebesar $34,76 \%$ nilai tingkat kemerahan (a*) sebesar 61,85\%, namun penyebabkan kenaikan nilai tingkat kecerahan $\left(\mathrm{L}^{*}\right)$ sebesar 70,91\%, nilai tingkat kekuningan $\left(\mathrm{b}^{*}\right)$ sebesar $67,21 \%$ terhadap kontrol.

\section{Saran}

Berdasarkan hasil penelitian disarankan penyimpanan ekstrak pewarna dari bunga kenop dilakukan pada $\mathrm{pH}$ awal 4 dan suhu $\left(4 \pm 1^{\circ} \mathrm{C}\right)$. Ekstrak pewarna dari bunga kenop sebaiknya diaplikasikan pada produk yang memiliki karakteristik $\mathrm{pH} 4$ dengan suhu penyimpanan pada suhu dingin.

\section{DAFTAR PUSTAKA}

Asra, R., Z. Azizah, R. D. Yetti, D. Ratnasari, B. Chandra, S. Misfadhila. 2020. Studi fisikokimia ekstrak umbi bit merah ( Beta vulgaris L.) sebagai pewarna pada sediaan tablet. Jurnal Farmasi Higea.12(1):65-74.

Azeredo, H.M.C. 2009. Betalains : properties, sources, application, and stability- a review. International Journal of Food Science and Technology. 44:2365-2376.

Bora, D. J., A. K. Gupta, F. A. Khan. 2015. Comparing the performance of $\mathrm{L}^{*} \mathrm{a} * \mathrm{~b}^{*}$ and hsv color spaces with respect to color image segmentation. International Journal of Emerging Technologi and Advanced Engeneering. 5(2):192-203.

Cai, Y., M. Sun and H. Corke. 2001. Identification and distribution of simple and acylated betacyanins in the amarantaceae. Jurnal Agric Food Chemistry. 49: 1971-1978.

Darwis, D. 2000. Teknik Dasar Laboratorium dalam Penelitian Senyawa Bahan Alam Hayati. Workshop Pengembangan 
Sumber Daya Manusia dalam Bidang Kimia Organik Bahan Alam Hayati. FMIPA Universitas Andalas. Padang.

Eder, R. 1996. Handbook of Food Analysis, Volume I. Marcel Dekker Inc, New York.

Estiasih, T., dan K. Ahmadi. 2014. Teknologi Pengolahan Pangan. Bumi Aksara, Jakarta.

Fikri, Z., N. M. Wartini, L. P. Wrasiati. 2020. Karakteristik ekstrak pewarna alami bunga kenop (Gomphrena globosa L.) pada perlakuan jenis pelarut dan suhu ekstraksi serta korelasi antar variabel. Jurnal Rekayasa Dan Manajemen Agroindustri. 8(3): 460-471.

Ginting, R. B., N. M. Wartini, L..P. Wrasiati. 2020. Karakteristik ekstrak pewarna alami bunga kenop (Gomphrena globosa L.) pada perlakuan ukuran partikel dan lama maserasi serta korelasi antar variabel. Jurnal Rekayasa Dan Manajemen Agroindustri. 8(3): 448-459.

Herbach, K.M., F. C. Stinizing, R. Carle. 2006. Betalain stability and degradation structural and chromatic aspects. Journal Science of food. 71(4): 41-50.

Indriyani, N. M. D., N. M. Wartini, N. P. Suwariani. 2018. Stabilitas karotenoid ekstrak pewarna buah pandan (Pandanus tectorius) pada suhu dan ph awal penyimpanan. Jurnal Rekayasa dan Manajemen Agroindustri. 6(3):211-217.

Khuluq, A. D., S. B. Widjanarko, E. S. Murtini. 2007. Ekstraksi dan stabilitas betasianin daun darah (Alternanthera dentata) (kajian perbandingan pelarut air:etanol dan suhu ekstraksi). 8(3): 172-181.

Otalora, C. M., E. L. Bonifaz, E. N. Fissore,
M. F. Basanta, L. N. Gerschenson. 2020. Thermal stability of betalains in by-products of the blanching and cutting of Beta vulgaris L. var conditiva. Journal of Food and Nutrition Sciences. 70(1): 15-24.

Paranoan, C. A. C, Lahming, Kadirman. 2017. Optimalisasi konsentrasi asam tartrat dan waktu ekstraksi pada ekstraksi pigmen betasianin dari kulit buah naga merah (Hylocereus polyrhizus) sebagai pewarna alami. Jurnal Pendidikan Teknologi Pertanian. 3: S126-S133.

Rengku, P. M., A. Ridhay. 2017. Ekstraksi dan uji stabilitas betasianin dalam ekstrak buah kaktus (Opuntia elatior Mill.). Jurnal Riset Kimia. 3(2): 142149.

Satriyanto, B., S.B. Widjanarko, Yunianta. 2012. Stabilitas warna ekstrak buah merah (Pandanus conoideus) terhadap pemanasan sebagai sumber potensial pigmen alami. J. Teknol Pertanian. 13 (3):157-168.

Sumonsiri N., and Sheryl AB. 2014. Food Processing: Principles and Applications. Fruits and VegetablesProcessing Technologies and Application. Second Edition. John Wiley \& Sons, Ltd. P 363- 381.

Sutrisno, A.D. 1987. Pembuatan dan Peningkatan Kualitas Zat Warna Merah Alami yang dihasilkan oleh Monascus purpureus. PAU Pangan dan Gizi IPB. Bogor.

Tang, C. S., Norziah, M.H. 2007. Stability of betacyanin figments from red purple pitaya fruit (Hylocereus polyrhizus) :influence of $\mathrm{pH}$, temperature, metal ions and ascorbic acid. Indonesian Journal of Chemistry. 7(3): 327-331.

Wijayakusuma, H.M.H. 2000. Ensiklopedia 
Milenium Tumbuhan Berkhasiat Obat Indonesia. Jakarta. Prestasi Insan Indonesia.

Yudharini, G. A. K. F., A. A. P. A. S. Wiranata, N. M. Wartini. 2016. Pengaruh perbandingan bahan dengan pelarut dan lama ekstraksi terhadap rendemen dan karakteristik ekstrak pewarna dari buah pandan (Pandanus tectorius). Jurnal Rekayasa dan Manajemen Agroindustri. 4(3): 36-46.
Zakharova Ns, Petrova Ta. 2000. betaGlucosidase of leaves and root of the common beet Beta vulgaris. Applied Biochemistry and Microbiology. 36: 458-461.

\section{UCAPAN TERIMAKASIH}

Ucapan terimakasih kepada Universitas Udayana yang telah mendanai penelitian ini melalui Skim Penelitian Unggulan Udayana Tahun 2021 yang diketuai oleh Dr. Ir. Ni Made Wartini, M.P. 